\title{
Identification of a Peptide for Systemic Brain Delivery of a Morpholino Oligonucleotide in Mouse Models of Spinal Muscular Atrophy
}

\author{
Fazel Shabanpoor, ${ }^{1, *, \dagger}$ Suzan M Hammond, ${ }^{2, \dagger}$ Frank Abendroth,, Gareth Hazell, \\ Matthew J.A. Wood, and Michael J. Gait ${ }^{1}$
}

Splice-switching antisense oligonucleotides are emerging treatments for neuromuscular diseases, with several splice-switching oligonucleotides (SSOs) currently undergoing clinical trials such as for Duchenne muscular dystrophy (DMD) and spinal muscular atrophy (SMA). However, the development of systemically delivered antisense therapeutics has been hampered by poor tissue penetration and cellular uptake, including crossing of the blood-brain barrier (BBB) to reach targets in the central nervous system (CNS). For SMA application, we have investigated the ability of various BBB-crossing peptides for CNS delivery of a splice-switching phosphorodiamidate morpholino oligonucleotide (PMO) targeting survival motor neuron 2 (SMN2) exon 7 inclusion. We identified a branched derivative of the well-known ApoE (141-150) peptide, which as a PMO conjugate was capable of exon inclusion in the CNS following systemic administration, leading to an increase in the level of full-length SMN2 transcript. Treatment of newborn SMA mice with this peptide-PMO (P-PMO) conjugate resulted in a significant increase in the average lifespan and gains in weight, muscle strength, and righting reflexes. Systemic treatment of adult SMA mice with this newly identified P-PMO also resulted in small but significant increases in the levels of SMN2 pre-messenger RNA (mRNA) exon inclusion in the CNS and peripheral tissues. This work provides proof of principle for the ability to select new peptide paradigms to enhance CNS delivery and activity of a PMO SSO through use of a peptide-based delivery platform for the treatment of SMA potentially extending to other neuromuscular and neurodegenerative diseases.

Keywords: brain delivery, peptides, spinal muscular atrophy, splice-switching oligonucleotide, survival motor neuron

\section{Introduction}

$\mathbf{S}^{\mathrm{n}}$ PINAL MUSCULAR ATROPHY (SMA) is an inherited motor neuron disease and a leading genetic cause of infant mortality. It is characterized by the loss of lower motor neurons, which results in progressive atrophy of voluntary muscle groups leading to paralysis and eventually premature death [1]. It is caused by the deletion of the survival motor neuron 1 (SMN1) gene in more than $95 \%$ of SMA patients [2]. Humans have a second nearly identical copy of this gene, SMN2 [2]. The majority ( $\sim 90 \%$ ) of SMN2 transcripts lack exon 7 due to a translationally silent $\mathrm{C}$-to-T transition +6 nucleotides within exon 7 [2-4]. Skipping of exon 7 during pre-messenger RNA (mRNA) splicing leads to the production of a truncated and only marginally functional SMN protein product [5]. The 10\% of SMN2 transcripts that contain exon 7 and which produce full-length functional SMN protein cannot adequately compensate for the loss of SMN1 unless high copy numbers of $S M N 2$ are present, in which case the severity of the disease is reduced [6,7]. Therefore, the focus of most current therapeutic strategies is to increase the expression of SMN protein by induction of exon 7 inclusion in SMN2.

The use of splice-switching oligonucleotides (SSOs) to modulate pre-mRNA splicing through a steric blocking mechanism

\footnotetext{
${ }^{1}$ Medical Research Council, Laboratory of Molecular Biology, Cambridge, United Kingdom.

${ }^{2}$ Department of Physiology, Anatomy, and Genetics, University of Oxford, Oxford, United Kingdom.

*Current affiliation: Howard Florey Research Laboratories, The Florey Institute of Neuroscience \& Mental Health, University of Melbourne, Melbourne, Australia.

$\dagger$ These authors contributed equality to this work and are considered co-first authors.

(C) Fazel Shabanpoor et al. 2017; Published by Mary Ann Liebert, Inc. This is an Open Access article distributed under the terms of the Creative Commons Attribution License, which permits unrestricted use, distribution, and reproduction in any medium, provided the original work is properly cited. Mary Ann Liebert, Inc. offers reprint services for those who want to order professionally produced copies of articles published under the Creative Commons Attribution (CC BY) license. To obtain a price quote, email Reprints@liebertpub.com. Please include the article's title or DOI, quantity, and delivery destination in your email.
} 
has provided a platform to target disease-causing mutations in several neuromuscular diseases and in particular Duchenne muscular dystrophy (DMD) [8] and SMA [9]. In the case of DMD, Phase III clinical trials by Biomarin have been recently completed that utilized $2{ }^{\prime}-O$-methyl-modified phosphorothioate (2'-OMe/PS) SSOs to target the removal of exon 51 (exon skipping) to correct out-of-frame mutations in amenable DMD patients. Unfortunately, improvement in a clinical measure of function, the 6-min walk test, was deemed insufficient for FDA approval of the drug.

By contrast, following small-scale Phase II/III clinical trials (Sarepta Therapeutics), a phosphorodiamidate morpholino oligonucleotide (PMO) also targeting exon 51, called Eteplirsen, has recently been approved for clinical use, despite relatively modest improvements in the 6-min walk test and the patient sample being small. For the treatment of SMA, an SSO is being developed by Ionis/Biogen Pharmaceuticals for use in infants and children, which has progressed to phase III clinical trials after promising data from open-label phase II studies and this drug, called Nusinersen, is expected to be approved soon for clinical use [10]. However, this type of SSO is not able to cross the blood-brain barrier (BBB) to reach the target motor neurons in central nervous system (CNS), hence the need for delivery through intrathecal injection to obtain broad CNS distribution. In a recent study on intrathecal administration of Nusinersen (ISIS-SMNRx), it was reported that, despite its great effectiveness, $32 \%$ of patients have developed side effects such as headache, back pain, and postlumbar puncture syndromes [11], possibly due to the use of an intrathecal delivery technique. There is thus a strong impetus to explore the development of noninvasive and efficient delivery systems for therapeutic SSOs to enter brain and spinal cord through the circulation.

For both DMD and SMA treatment so as to reduce dosages needed (which for PMO use in DMD is very high), there is an additional requirement to improve penetration into muscle and other relevant organ types following systemic delivery, as well as into the required cell types within such organs. Despite the transduction efficiency of viral gene delivery, the use of viral delivery vehicles is limited due to the immunotoxicity of the viral coat protein and potential oncogenic effects [12]. However, in the case of neuromuscular diseases, considerable progress has been made in the use of nonviral delivery vectors, particularly synthetic cell-penetrating peptides (CPPs). In the case of DMD, conjugations of various Arg-rich peptides to exon skipping PMOs have given rise to dramatic improvements in levels of in vivo dystrophin production in skeletal muscles in mouse models [13-17], and we have extended this to heart muscles using a new range of such peptides known as Pip [18,19]. In very recent studies in SMA mouse models, we have found that a conjugate of PMO to Pip6a peptide, following intravenous delivery, was able to direct significant exon inclusion in the brains and spinal cords of SMA model mice in addition to skeletal muscles [20].

Synthetic peptides have also shown considerable promise for some years for delivery into the CNS due to their small size, low toxicity, targeting specificity, and ability of transcapillary delivery of large bio-cargoes [21-23]. Several peptides have been reported for their BBB permeability either alone or carrying a bio-cargo [22,24-27]. Thus, in parallel to our recent study of the Arg-rich Pip6a peptide as a PMO carrier into brain and spinal cord of an SMA mouse, we asked whether it was possible to identify other peptide types capable of simultaneously enhancing muscle cell penetration of a PMO bio-cargo into skeletal muscle tissue as well as delivering a splice-switching PMO into the CNS of SMA mice. Thus, we screened and tested two main types of alternative peptide-PMO (P-PMO) conjugates, in one case where the peptide component might be expected to utilize a receptor-mediated BBB transcytosis mechanism as well as in the other case some cationic P-PMOs that might be subject to absorptive-mediated BBB transcytosis similar to Pip6a.

Before detailed in vivo testing in SMA mice, we wished to exclude peptides that, as PMO conjugates, did not lead to sufficiently enhanced cell uptake and activity, which is extremely important to obtain in addition to enhanced BBB crossing. Thus, we first used a two-stage cellular spliceswitching screen to gauge the cell uptake efficiency and the pre-mRNA targeting ability of these conjugates. Preliminary screening for muscle cell penetration was carried out using the well-established exon-skipping assay in the DMD mouse $m d x$ muscle cell line that has a high dynamic range. A secondstage testing then involved induction of SMN2 exon 7 inclusion in a human SMA patient-derived fibroblast cell line. Several of the most cell-active peptides that passed both these screens were then tested as PMO conjugates in a newborn mouse model of SMA carrying a human SMN2 transgene, by measurement of the level of exon 7 inclusion after intravenous injection at postnatal day 4 (PND4). This led to the identification of a branched ApoE $(\mathrm{K} \rightarrow \mathrm{A})$ peptide candidate, which as a PMO conjugate was demonstrated to show a dramatic improvement in the lifespan of homozygous newborn SMA mice with median lifespan $\sim 15$ days [28] to 78 days and two SMA mice surviving to 280-290 days. The ability of this branched peptide in delivery of exon-including PMO into the CNS was then also evaluated in adult SMA mice through intravenous administration and we showed that it is able to deliver PMO into the CNS and restore full-length SMN2 pre-mRNA.

\section{Materials and Methods}

\section{Materials}

9-Fluorenylmethoxycarbonyl (Fmoc)-protected L- $\alpha$ amino acids and coupling reagents (HBTU and PyBOP) and the Fmoc-Gly-OH-preloaded Wang resin $(0.19 \mathrm{mmol} / \mathrm{g})$ were obtained from Merck (Hohenbrunn, Germany). Fmoc-L-bishomopropargylglycine-OH (Bpg) was purchased from Chiralix (Nijmegen, Germany). Chicken embryo extract (CEE) and horse serum for cell culture were obtained from Sera Laboratories International Ltd. (West Sussex, UK). $\gamma$-Interferon was obtained from Roche Applied Science (Penzberg, Germany). The High-Capacity cDNA RT Kit was from Applied Biosystems (Warrington, UK), Power SYBR Green PCR Master Mix from Life Technology (Paisley, UK), and Primers from Integrated DNA Technologies (Leuven, Belgium). PMO was fromGene Tools, LLC (Philomath, OR). Cy5-azide was from Lumiprobe (Hallandale Beach, FL). All other reagents were obtained from Sigma-Aldrich (St. Louis, MO).

\section{Peptide synthesis}

All linear peptides were synthesized using Fmoc chemistry as C-terminal free carboxylic acid using Fmoc-Gly-OHpreloaded Wang resin on a CEM Liberty ${ }^{\mathrm{TM}}$ microwave peptide synthesizer (Buckingham, UK). Standard trifluoroacetic 
acid (TFA)-labile side-chain-protecting groups were used for all amino acids, except for Lys, Asp, and Glu, which were protected by hydrazine-labile-protecting groups (ivDde on Lys and ODmab on Asp and Glu). All peptides included a C-terminal Bpg residue and were synthesized at $0.1 \mathrm{mmol}$ scale using an excess of Fmoc-protected amino acids, PyBOP, and DIPEA $(5: 5: 10)$ at $75^{\circ} \mathrm{C}$ for $5 \mathrm{~min}$. Fmoc-Lbis-homopropargylglycine-OH (Bpg) was purchased from Chiralix (Nijmegen, The Netherlands). The $N$ - $\alpha$-Fmocprotecting groups were removed using piperidine in DMF $(20 \%$ $\mathrm{v} / \mathrm{v})$ at $75^{\circ} \mathrm{C}$ for $3 \mathrm{~min}$. To prevent racemization, the cysteine and histidine residues were coupled at $50^{\circ} \mathrm{C}$ for $10 \mathrm{~min}$.

The peptide chain was cleaved from the solid support by treatment with a cocktail of TFA:3,6-dioxa-1, 8-octanedithiol (DODT):water: triisopropylsilane [TIPS; (94\%:2.5\%:2.5\%:1\%), $10 \mathrm{~mL}$ ] for $90 \mathrm{~min}$. Peptides were precipitated in ice-cold diethyl ether and the peptide pellets were washed three times in ice-cold diethyl ether. PepC7 and branched (Br) PepC7 peptides were further modified postsynthesis by formation of a disulfide bond. The first disulfide bond was easily formed by oxidizing the cysteine residues by first dissolving the linear peptide in $0.1 \mathrm{M} \mathrm{NH}_{4} \mathrm{HCO}_{3}$ solution $(1 \mathrm{mg} / 3 \mathrm{~mL}$, $\mathrm{pH}$ 8) followed by addition of a $1 \mathrm{mM}$ solution of $2,2^{\prime}$ dipyridyldisulfide (DPDS) in methanol $(0.2 \mathrm{~mL} / 1 \mathrm{mg})$. Since there was no change in the retention time of the oxidized peptide, the formation of a disulfide bond was confirmed by the Ellman's test [29]. The formation of the second disulfide bond was carried out by simultaneous removal of Acm-protecting groups and oxidation of cysteines. Br-PepC7 was dissolved in acetic acid $(2 \mathrm{mg} / \mathrm{mL})$ and $60 \mathrm{mM} \mathrm{HCl}$ solution $(5 \% \mathrm{v} / \mathrm{v})$ was added followed by addition of iodine (10 eq/Acm) as a $20 \mathrm{mM}$ solution. The progress of the reaction was monitored using reversed-phase high performance liquid chromatography (RP-HPLC). Due to the slow rate of oxidation, the amount of iodine was increased to $20 \mathrm{eq} / \mathrm{Acm}$ group. Following the completion of the reaction after $30 \mathrm{~min}$, the peptide was precipitated in cold diethyl ether. The peptide pellet was dissolved in water and $20 \mathrm{mM}$ ascorbic acid solution was added to quench the remaining traces of iodine. All peptides were purified $(>90 \%)$ using preparative RP-HPLC on a Phenomenex column $(21.2 \times 150 \mathrm{~mm}, \mathrm{C} 18,5 \mu \mathrm{m})$ using a $0.1 \%$ TFA-based buffer. MALDI-TOF mass spectrometry (ABI Voyager DE Pro) was used to characterize the peptides using either $\alpha$ cyano-4-hydroxycinnamic acid or sinapic acid matrices.

\section{P-PMO conjugation}

The 20-mer PMO sequences for human SMN2 exon-7 inclusion [5'-ATTCACTTTCATAATGCTGG-3', targeting intron splice silencer N1 (ISS-N1) at the $5^{\prime}$ region of intron 7] [30], a control scrambled sequence for SMN2 (5'-ATTG TCTATCAAAATCCTGC-3') and the 25-mer PMO sequence for exon-23 skipping of $D m d$ pre-mRNA (5'-GG CCAAACCTCGGCTTACCTGAAAT-3') were obtained from Gene Tools, LLC. The purified peptides were conjugated to the PMOs through an amide bond between the free carboxyl group at the $\mathrm{C}$-terminal of the peptides and a secondary amino group at the $3^{\prime}$-end of the PMO. Peptides were dissolved in NMP to a concentration of $50 \mathrm{mM}$ and the PMO was dissolved in dimethyl sulfoxide (DMSO) to a final concentration of $10 \mathrm{mM}$. A 2.5-fold excess of peptide over PMO was used. The peptides were activated using HBTU:HOBt (2.5:2) and con- jugated to the PMO in the presence of a fourfold excess of DIEA. The reaction was carried out at $40^{\circ} \mathrm{C}$ for $2 \mathrm{~h}$. Some of the P-PMOs were treated with hydrazine (20 eq) for a further 15 min to deprotect the ivDde and ODmab-protecting groups before purification. The positively charged P-PMOs were purified on a high-resolution-16/10 cation-exchange column (GE Healthcare) using $25 \mathrm{mM}$ sodium phosphate buffer $(\mathrm{pH}$ 7.2) containing $25 \%$ acetonitrile. The same buffer with $1 \mathrm{M}$ $\mathrm{NaCl}$ added was used to elute the P-PMO. The removal of excess salts was achieved by centrifugation using an Amicon ${ }^{\circledR}$ Ultra-15 3K centrifugal filter device. The P-PMOs with no positive charge were purified using RP-HPLC with a $0.1 \%$ TFA buffer. The trifluoroacetate counter ions were removed by dissolving the lyophilized $\mathrm{P}-\mathrm{PMO}$ in $5 \mathrm{mM} \mathrm{HCl}$ solution and filtered as above [31]. The concentrate $(\sim 300 \mu \mathrm{L})$ was washed three times with deionized water to remove excess $\mathrm{HCl}$ before lyophilization. The overall yields of P-PMO conjugates ranging from $30 \%$ to $45 \%$ based on the starting amount of PMO as determined by ultraviolet absorbance at $265 \mathrm{~nm}$.

\section{Mouse exon skipping $\mathrm{mdx}$ cell assay}

Mouse $\mathrm{H} 2 \mathrm{~K} m d x$ myoblasts were maintained in highglucose Dulbecco's modified Eagle's medium (DMEM) containing $20 \%$ fetal calf serum, $2 \% \mathrm{CEE}$, and $0.002 \%$ of interferon $-\gamma$ at $33^{\circ} \mathrm{C}$. The myoblasts were differentiated into myotubes for the exon-skipping assay as previously described [32]. The exon-skipping assay was carried out by incubating the myotubes with appropriate concentrations of P-PMOs dissolved in serum-free Opti-MEM for $4 \mathrm{~h}$ at $37^{\circ} \mathrm{C}$. The transfection medium was then replaced with DMEM/5\% horse serum and cells incubated for a further $20 \mathrm{~h}$ at $37^{\circ} \mathrm{C}$. The level of exon-23 skipping for tandem ApoE-PMO and branched ApoE $(\mathrm{K} \rightarrow \mathrm{A})$-PMO was also measured in the presence of serum. The P-PMOs $(1 \mu \mathrm{M})$ were preincubated in $50 \%$ mouse serum for 1 and $2 \mathrm{~h}$ before transfecting the cells. Total RNA was isolated from $\mathrm{H} 2 \mathrm{~K} m d x$ cells using TRIzol ${ }^{\circledR}$ (Sigma, UK). RNA (500 ng) was used to carry out complementary DNA (cDNA) synthesis and primary polymerase chain reaction (PCR) amplification of dystrophin DMD transcripts using SuperScript III One-Step RT-PCR System with Platinum Taq DNA polymerase (Invitrogen) as previously described [32]. The primers used for the first PCR amplification were DysEx20Fo (5'-CAGAATTCTGCC AATTGCTGAG) and DysEx26Ro (5'-TTCTTCAGCTTG TGTCATCC). The second PCR was carried out using $1 \mu \mathrm{L}$ of the first PCR as template using SuperTaq Polymerase (H T Biotechnology Ltd.) and primed by DysEx20Fi (5'CCCAGTCTACCACCCTATCAGAGC) and DysEx26Ri (5'-CCTGCCTTTAAGGCTTCCTT). PCR products were fractionated by $2 \%$ agarose gel and scanned using GelDoc Imaging System (Bio-Rad). The area density of each band was determined using Image Lab software (Bio-Rad). The relative amount of exon-23 skipping was expressed as a percentage of total Dmd transcripts at a given concentration of P-PMOs conjugates. Data were expressed as mean \pm standard error of the mean (SEM) from at least three independent experiments.

\section{Cell viability assessment}

The P-PMOs were assessed for their cytotoxicity in human hepatocyte cells (Huh-7) using 3-(4,5-dimethylthiazol-2-yl)-5- 
(3-carboxymethoxyphenyl)-2-(4-sulfophenyl)-2H-tetrazolium (MTS) cell viability assay as previously described [32]. Briefly, Huh-7 cells were plated in a 96-well plate and treated with P-PMOs at a relatively high concentration of $40 \mu \mathrm{M}$. The level of cell viability was measured using CellTiter $96^{\circledR}$ AQueous One Solution Reagent (Promega) according to the manufacturer's instructions. Untreated cells were used as control and the viability of treated cells were expressed as percentage of control.

\section{Human SMA fibroblast exon inclusion assay}

Following screening of the P-PMO conjugates in the $m d x$ cell assay for cell internalization and exon-skipping efficacy, several of them [rabies virus glycoprotein (RVG), AngioPep2, THR, PepC7, SynB3PFV, and Br-ApoE $(\mathrm{K} \rightarrow \mathrm{A})$ ] were further tested for splice-switching activity in an SMA patientderived fibroblast cell assay by measurement of the percentage increases in the level of full-length SMN2 transcript using real time-polymerase chain reaction (RT-PCR). Briefly, SMA fibroblast cells (GM03813; Coriell) were plated at a density of $250 \times 10^{3}$ cells $/ \mathrm{mL}$ in a six-well plate. Cells were treated at three different concentrations of P-PMOs $(300,600$, and 1,200 nmol). The PCR was carried out by use of a two-step protocol. Total RNA obtained from the SMA patient cell line was extracted with TRI Reagent (Sigma-Aldrich). One microgram of total RNA in $15 \mu \mathrm{L}$ of DEPC-treated water and $2 \mu \mathrm{L}$ (100 pmol) of Oligo dT18 primer (Sigma-Aldrich) was used for cDNA first-strand synthesis. The reaction mixture was incubated at $65^{\circ} \mathrm{C}$ for $5 \mathrm{~min}$ and placed on ice. Afterward, $2.5 \mu \mathrm{L}$ of a dNTP stock solution $(10 \mathrm{mM}$; GE Healthcare), $2.5 \mu \mathrm{L}$ $10 \times$ Super RT-buffer (H T Biotechnology Ltd.), $0.5 \mu \mathrm{L}$ RNasin (Promega), $0.25 \mu \mathrm{L}$ Super RT (H T Biotechnology Ltd.), and $2.25 \mu \mathrm{L}$ DEPC-treated water was added, and the reaction mixture was incubated for $40 \mathrm{~min}$ at $42^{\circ} \mathrm{C}$. Subsequently $5 \mu \mathrm{L}$ of the RT-PCR product was then used as the template for the primary PCR carried out in $25 \mu \mathrm{L}$ volumes with $0.5 \mathrm{U}$ Taq DNA Polymerase (H T Biotechnology Ltd.) using oligonucleotides 5'-CTCCCATATGTCCAGATTCTCTT-3' as forward primer and 5'-CTACAACACCCTTCTCACAG-3' as reverse primer. The cycle conditions were $95^{\circ} \mathrm{C}$ for $1 \mathrm{~min}, 57^{\circ} \mathrm{C}$ for $1 \mathrm{~min}$, and $72^{\circ} \mathrm{C}$ for $2 \mathrm{~min}$ and finally $72^{\circ} \mathrm{C}$ for $10 \mathrm{~min}$ for 25 cycles. The PCR products were analyzed in a $2 \%$ agarose gel in $0.5 \%$ TBE buffer and the bands were visualized by SYBR Safe (Invitrogen, Molecular Probes) Staining. Gels were documented using the GelDoc Imaging System (Bio-Rad).

\section{Treatment of newborn SMA mice and assessment of SMN2 exon 7 inclusion and phenotype}

Experiments were carried out in the Biomedical Sciences Unit, University of Oxford, according to procedures authorized by the UK Home Office and approved by the Unit Approval Board. Experiments were carried out using the SMAlike mouse strain FVB.Cg-Smn $1^{\text {tm1Hung }} \mathrm{Tg}(\mathrm{SMN} 2) 2 \mathrm{Hung} / \mathrm{J}$. For the purposes of welfare, the peptide screen was carried out on hemizygotic (Smn $1^{\text {tm1Hung/wt }}$;SMN $2^{\text {tg/tg }}$ ) pups generated as previously described [33]. Each litter $(n=4-6$ per P-PMO) at PND4 was injected with P-PMO (2.6 nmol) in 10$15 \mu \mathrm{L}$ of $0.9 \%$ saline. The control litter was injected with $0.9 \%$ saline. Neonatal mice were euthanized 7 days postinjection and brains, kidneys, and quadriceps were extracted and frozen on dry ice before RNA extraction. The Br-ApoE $(\mathrm{K} \rightarrow$
$\mathrm{A})$-PMO and $\mathrm{Br}-\mathrm{ApoE}(\mathrm{K} \rightarrow \mathrm{A})$-scrambled PMO were further analyzed in homozygotic pups (Smn $1^{\text {tm1Hung/tm1Hung }} ; \mathrm{SMN} 2^{\text {tg/o }}$ ) generated as previously described [33]. Pups used for phenotype assessment were injected with $10 \mu \mathrm{g} / \mathrm{g}(1 \mathrm{nmol}) \mathrm{Br}-$ ApoE $(\mathrm{K} \rightarrow \mathrm{A})$-PMO, Br-ApoE $(\mathrm{K} \rightarrow \mathrm{A})$-scrambled PMO, SMA-PMO through the facial vein at PND0 and PND2. Treated animals were weighed daily and observed for survival longevity. A humane endpoint was determined by mobility and weight. Animals who had reached their humane endpoint were euthanized by rising $\mathrm{CO}_{2}$.

Pups were also tested from PND2 to PND12 for hindlimb strength and negative geotaxis. Hindlimb strength was scored using a hindlimb suspension (HLS) test developed by PsychoGenics, Inc. and described in the standardized protocols and procedures for preclinical studies by TREAT-NMD. The HLS score relates to the position of the legs and tail of pups suspended by their hindlimbs onto the lip of a 50-cc test tube. A score of $0-4$ is given with the 0 relating to the weakest phenotype (feet clasped and tail down) and a 4 given to the strongest phenotype (legs spread and tail up) [34]. For the purposes of reproducibility, factors such as leg pulls and time were left out of the analysis. Righting reflex was measured by placing pups on their back and timing their ability to right themselves onto all four paws.

\section{Quantitative real-time PCR}

RNA was extracted from harvested tissues and reverse transcribed using the High Capacity cDNA RT Kit (Applied Biosystems) according to the manufacturer's instructions. Reactions contained $1 \mu \mathrm{g}$ RNA, RT Buffer, $4 \mathrm{mM}$ dNTP mix, RT random primers, and MultiScribe reverse transcriptase in a final volume of $10 \mu \mathrm{L}$. Quantitative real-time PCR analysis was carried out on a StepOnePlus Thermocycler using Power SYBER $^{\circledR}$ Green Master Mix (Applied Biosystems). Amplification of full-length SMN2 and total SMN2 transcripts was carried out using $20 \mathrm{ng}$ of the cDNA template in a total volume of $20 \mu \mathrm{L}$. The primers used for full-length SMN2 amplification (Forward Ex6; 5' GCT TTG GGA AGT ATG TTA ATT TCA $3^{\prime}$ and reverse Ex7-8 5' CTA TGC CAG CAT TTC TCC TTA ATT 3') and total SMN2 (Forward Ex2a; 5' GCG ATG ATT CTG ACA TTT GG 3' and reverse Ex2b 5' GGA AGC TGC AGT ATT CTT CT3') were obtained from Integrated DNA Technologies. The changes in the level of fulllength $S M N 2$ transcripts expression in various tissues were determined and normalized to the total SMN2 transcripts. Data were analyzed using Prism software (GraphPad Software, Inc., La Jolla, CA) and plotted as FLSMN2 expression relative to the saline-treated group. Data were expressed as mean \pm SEM. The statistical significances between saline-treated and PPMO-treated groups were determined using the Student's $t$ test. A $P$ value of $<0.05$ was considered statistically significant.

\section{Treatment of adult SMA mice}

Tail vein administration in adult mice was carried out in unaffected mice (Smn $1^{\text {tm1Hung/WT }} ; \mathrm{SMN} 2^{\text {tg/tg }}$ ) at $11-12$ weeks of age. Mice were given 6 weekly doses of $10 \mathrm{mg} / \mathrm{kg}$ bodyweight Br-ApoE $(\mathrm{K} \rightarrow \mathrm{A})-\mathrm{PMO}(n=4)$ and tissues were harvested 7 days post final administration. Age-matched control animals $(n=5)$ were given a single saline intravenously at $5 \mu \mathrm{L} / \mathrm{g}$ bodyweight and tissues harvested 7 days postadministration. 
Protein extraction and western blot

Protein was harvested from $\sim 300 \mathrm{mg}$ of tissue homogenized into RIPA Buffer [ $150 \mathrm{mM} \mathrm{NaCl}, 1 \%$ IGEPAL, $0.5 \%$ sodium deoxycholate, $0.1 \%$ sodium dodecyl sulfate (SDS), and $50 \mathrm{mM}$. Tris buffer ( $\mathrm{pH} \mathrm{8.6)]} \mathrm{with} \mathrm{complete} \mathrm{mini} \mathrm{pro-}$ teinase inhibitors (Roche Applied Science). Protein levels were measured by the Bradford assay (Sigma, St Louis, MO) and quantified using bovine serum albumin standards. Thirty to $40 \mu \mathrm{g}$ of protein was loaded onto $10 \%$ acrylamide gels. Protein was transferred onto a $0.45 \mu \mathrm{m}$ nitrocellulose membrane (Millipore) and probed for human SMN protein using anti-SMN, clone SMN-KH monoclonal IgG1 antibody (Millipore) at 1:1,000, and loading control, mouse $\beta$-tubulin using anti- $\beta$-actin monoclonal IgG2a antibody (Sigma) diluted in Odyssey ${ }^{\circledR}$ Blocking Buffer (LI-COR Biosciences, Lincoln, NE) at 1:100,000. Primary antibodies were detected with secondary antibody IRDye ${ }^{\circledR} 800 \mathrm{CW}$ goat anti-mouse IgG (LI-COR Biosciences). Membranes were then imaged on LI-COR Odyssey FC imager and analyzed with Image Studio ${ }^{\mathrm{TM}}$ software (LI-COR Biosciences, Lincoln, NE).

\section{Clinical biochemistry}

Serum from 5-week-old mice administered with two doses 2 days apart of $10 \mathrm{mg} / \mathrm{kg} \mathrm{Br}-\mathrm{ApoE}(\mathrm{K} \rightarrow \mathrm{A})-\mathrm{PMO}, \mathrm{Br}-\mathrm{ApoE}$ $(\mathrm{K} \rightarrow \mathrm{A})$-scrambled PMO or untreated control was extracted from the jugular vein upon harvest 7 days post final administration and analysis of toxicity biomarkers was performed by a clinical pathology laboratory, Mary Lyon Center, MRC (Harwell, UK).

\section{Results}

\section{Peptide synthesis}

We chemically synthesized a range of peptides (Table 1) that are analogues of endogenous peptides/proteins designed to bind to receptors at the $\mathrm{BBB}$ such as acetylcholine receptor (Ach-R), low-density lipoprotein receptor (LDLR), lipoprotein receptor-related protein 1 (LRP-1), apolipoprotein receptor (ApoER), transferrin receptor (TfR), or neuronal ganglioside receptor (GT1b-R). These peptides include RVG [35-37], Angiopep-2 [38], ApoE(141-150) [39,40], THR [41], and TET-1 [42]. In addition, we synthesized other peptides that were identified from phage display screens [PepC7 [43] and TGN [44], a peptide derived from the HSV glycoprotein (gH625) [45], a Protegrin peptide, SYNB3 [46], a hydrophobic peptide PFV [47], and a hybrid Protegrin-hydrophobic peptide (SynB3PFV)]. Some of these peptides are also highly cationic and might be expected to use an absorptive-mediated transcyotosis pathway of BBB crossing as an alternative or in addition to a receptor-mediated pathway. The cationic charge should also facilitate good cell uptake. Furthermore, two of these peptides were synthesized as double versions, either as linear tandem peptides (tandem ApoE) or branched (Br) peptides by branching through a Lys residue at the C-terminus [BrApoE and Br-PepC7 as well as a mutant $\mathrm{Br}-\mathrm{ApoE}(\mathrm{K} \rightarrow \mathrm{A})]$. All peptides were synthesized as $\mathrm{C}$-terminal carboxylic acids and furnished with a bis-homopropargylglycine (Bpg) residue to enable "click" conjugation to a fluorescent label [31]. They were purified to $>95 \%$ using RP-HPLC (eg, see Supplementary Fig. S1 [Supplementary Data are available online at www .liebertpub.com/nat] for purification of branched PepC7).

Table 1. Sequences of Peptides with Acetylated N-Terminus and Phosphorodiamidate Morpholino Oligonucleotide Is Conjugated to the C-Termini

\begin{tabular}{|c|c|}
\hline Peptide & Sequence \\
\hline RVG & A $\mathrm{C}$-YTIWMPENPRPGTPSDIFTNSRGKRASNGX-Bpg-G \\
\hline AngioPep-2 & AC-TFFYGGSRGKRNNFKTEEYX-Bpg-G \\
\hline ApoE (141-150) & Ac-LRKLRKRLLRX-Bpg-G \\
\hline TET-1 & AC-HLNILSTLWKYRX-Bpg-G \\
\hline THR & AC-THRPPMWSPVWPX-Bpg-G \\
\hline gH625 & AC-HGLASTLTRWAHYNALIRAFGGGX-Bpg-G \\
\hline PFV & $A C-P F V Y L I X-B p g-G$ \\
\hline SynB3 & AC-RRLSYSRRR $\mathrm{R}-\mathrm{Bp} g-\mathrm{G}$ \\
\hline SynB3PFV & Ac-RRLSYSRRRFPFVYLIX-Bpg-G \\
\hline TGN & AC-TGNYKALHPHNGX-Bpg-G \\
\hline PepC7 & Ac-CTSTSAPYC $X-B p g-G$ \\
\hline Tandem ApoE & A C-LRKLRKRLLRLRKLRKRLLRX-Bpg-G \\
\hline Branched ApoE & AC-LRKLRKRLLRGG \\
\hline Branched ApoE (K-A) & $\begin{array}{l}\text { A C-LRKLRKRLLRGGKX-Bpg-G } \\
\text { A } \mathrm{C}-\text { LRALRARLLRGG } \\
\text { Ac-LRALRARLLRGGKX-Bpg-G }\end{array}$ \\
\hline Branched PepC7 & $\begin{array}{l}\text { Ac-CTSTSAPYC } G G \\
\text { Ac-CTSTSAPYCCGGKX-Bpg-G }\end{array}$ \\
\hline Branched PepC7/ApoE & $\begin{array}{l}\text { A } C \text {-CTSTSAPYC } G G \\
\text { AC-IRALRARLLRGGKX-Bpg-G }\end{array}$ \\
\hline
\end{tabular}

Residues in bold represent the originally named peptide.

Ac, acetyl; Bpg, bishomopropargylglycine; RVG, rabies virus glycoprotein; X, aminohexanoic acid. 

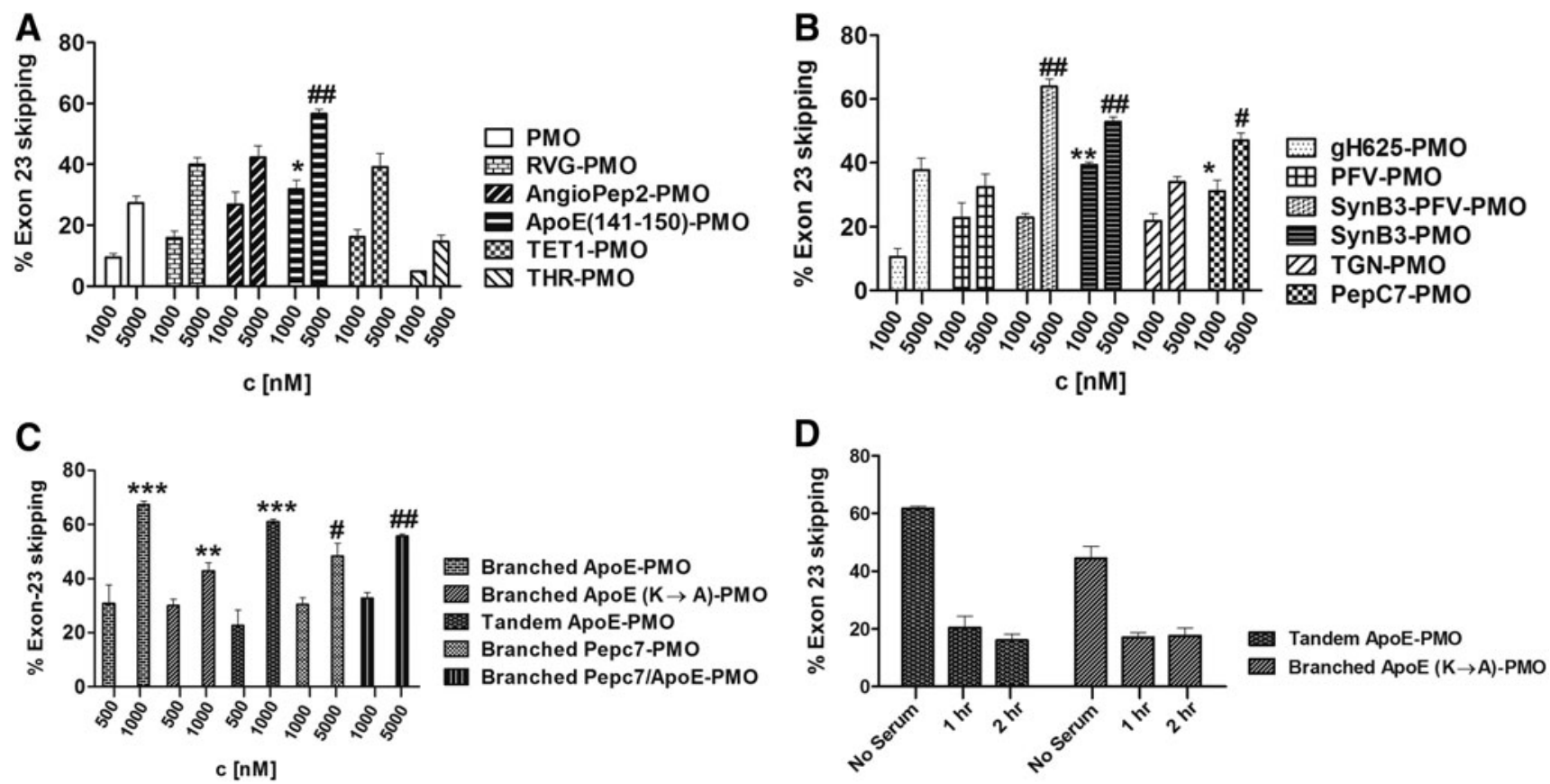

FIG. 1. Splice-switching activity of P-PMO conjugates in H2K $m d x$ muscle cells measured using nested real timepolymerase chain reaction (RT-PCR) at 1 and $5 \mu \mathrm{M}$. (A) DMD exon-23 skipping of receptor-targeting peptides conjugated to PMO. (B) Exon-23 skipping activity of P-PMOs with peptides of unknown BBB crossing mechanism. (C) Branched and tandem dimers of ApoE conjugates $(0.5$ and $1 \mu \mathrm{M})$ showing higher exon-23 skipping activities than single ApoE-PMO (1 and $5 \mu \mathrm{M})$. The branched analogue of PepC7 and the branched chimera of ApoE-PepC7-PMO showed similar exonskipping levels to the monomer of PepC7 at 1 and $5 \mu \mathrm{M}$. (D) Assessment of proteolytic stability of tandem ApoE-PMO and branched ApoE-PMO $(\mathrm{K} \rightarrow \mathrm{A})$ at $1 \mu \mathrm{M}$ was measured by preincubating the P-PMOs in $50 \%$ mouse serum for 1 and $2 \mathrm{~h}$. The level of $D M D$ exon-23 skipping was significantly decreased after $1 \mathrm{~h}$ and remained unchanged after $2 \mathrm{~h}$. $* P<0.05$, $* * P<0.001$, *** $P<0.0001$ cf. PMO $(1 \mu \mathrm{M})$; ${ }^{\#} P<0.05$, ${ }^{\# \#} P<0.001$ cf. PMO $(5 \mu \mathrm{M})$. BBB, blood-brain barrier; DMD, Duchenne muscular dystrophy; PMO, phosphorodiamidate morpholino oligonucleotide; P-PMO, peptide-PMO.

\section{PMO conjugation and cellular assays as measures of cell uptake ability}

Before in vivo testing, we screened the peptides as PMO conjugates in two cellular assays to determine those peptides capable of enhancing cellular uptake and pre-mRNA targeting by PMO. First, we conjugated the peptides to a wellvalidated 25-mer Dmd PMO sequence and measured spliceswitching activity in differentiated $\mathrm{H} 2 \mathrm{~K}$ skeletal muscle $m d x$ cells through measurement of the levels of $D M D$ exon-23 skipping [19,48-51]. This cell assay has a very high dynamic range and is thus a good primary screen for general cell delivery and RNA-targeting ability. All P-PMO conjugates showed a concentration-dependent increase in exon-23 skipping (Fig. 1A-C). Among the P-PMOs designed for BBB receptor targeting, ApoE (141-150)-PMO conjugate showed the highest exon-skipping activity in $m d x$ cells that was statistically greater than that for PMO alone (Fig. 1A). In the cases of P-PMOs, where the peptide component has an unknown mode of BBB crossing, SynB3-PMO, SynB3-PFV$\mathrm{PMO}$, and PepC7-PMO showed exon-23 skipping activity in $m d x$ cells higher than that of the naked PMO (Fig. 1B). The branched and linear dimers of ApoE showed significantly higher activity at lower concentrations than for the monomeric ApoE (141-150)-PMO (Fig. 1C), whereas PMO conjugates of a dimer of PepC7 and the chimera of ApoE-PepC7 did not improve exon skipping activity of single P-PMOs (Fig. 1C). The modified branched construct Br-ApoE-PMO
$(\mathrm{K} \rightarrow \mathrm{A})$ was equally active in exon skipping as its unmodified counterpart at $500 \mathrm{nM}$, but at $1 \mu \mathrm{M}$ it was less active than its counterpart (Fig. 1C). In the case of the tandem ApoE$\mathrm{PMO}$ and the branched $\mathrm{Br}-\mathrm{ApoE}(\mathrm{K} \rightarrow \mathrm{A})$-PMO conjugates as a check on serum stability, exon skipping was also assessed after treatment of the conjugates with $50 \%$ mouse serum. Exon skipping levels decreased significantly for both P-PMOs after $1 \mathrm{~h}$ of serum treatment, but the level remained unaltered after $2 \mathrm{~h}$ treatment (Fig. 1D), which demonstrated that although the peptides are prone to proteolysis in serum, a reasonable level of splice-switching activity was nevertheless maintained.

As a measure of cytoxicity, P-PMOs showing the highest splice-switching activities were tested for cell viability in human hepatocytes following a 4-h incubation at $40 \mu \mathrm{M}$ (Fig. 2), since liver accumulation is well known for P-PMOs and other therapeutic oligonucleotide types. Compared with untreated cells, no significant reductions in cell viability were seen for any conjugate, except for the PMO conjugates of both the branched and tandem dimers of ApoE, where viability levels dropped to $<40 \%$. By contrast, the $\mathrm{K} \rightarrow \mathrm{A}$ analogue of the Br-ApoE showed significantly less cytotoxicity, with a cell viability of $>85 \%$. Therefore, the $\mathrm{K} \rightarrow$ A analogue was used for all further work.

As a further test of cellular uptake and activity with more direct relevance to SMA, a number of selected peptides conveying high activity to PMO in the first round of screening were conjugated to a 20-mer PMO-targeting ISS- 


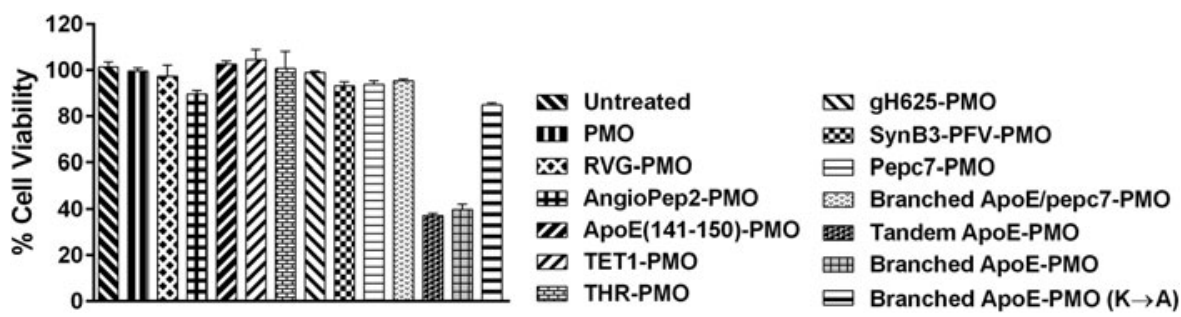

FIG. 2. Effect of P-PMO on the viability of human hepatocyte (Huh7) cells. All P-PMOs were tested at a relatively high concentration of $40 \mu \mathrm{M}$ and the cell viability was determined using an MTS assay. P-PMO conjugates showed no sign of cytotoxicity apart from branched and tandem ApoE, which caused significant cell death with $<40 \%$ cell viability. However, replacement of $\mathrm{K} \rightarrow \mathrm{A}$ in branched ApoE led to enhanced cell viability of $>85 \%$. MTS, 3-(4,5-dimethylthiazol-2-yl)-5-(3carboxymethoxyphenyl)-2-(4-sulfophenyl)-2H-tetrazolium.

N1 site at the $5^{\prime}$ region of intron 7 of SMN2 pre-mRNA [30] and evaluated for SMN2 exon 7 inclusion activity in the SMA type I fibroblast cell line. The level of full-length SMN2 premRNA increase following P-PMO treatment was measured using RT-PCR. Although the dynamic range of this cell assay is not as large as for the DMD $m d x$ muscle cells, all P-PMO conjugates tested showed concentration-dependent increases in the levels of full-length SMN2 mRNA in the fibroblast cell assay (Fig. 3). Whereas untreated cells showed a level of fulllength SMN2 pre-mRNA of ca. 65\%, SSO-treated cells showed increases up to $85 \%$ with the concentrations used. The Br-ApoE $(\mathrm{K} \rightarrow \mathrm{A})$-PMO conjugate showed the highest exon inclusion activity, which is consistent with the results obtained for the first round screening for $D M D$ exon skipping activity in $\mathrm{H} 2 \mathrm{~K} m d x$ cells. The $\mathrm{Br}-\mathrm{ApoE}(\mathrm{K} \rightarrow \mathrm{A})$ peptide conjugated to a scrambled PMO served as a negative control and showed no exon inclusion activity.

While these screening assays were in progress, for some of those peptides known to be $\mathrm{BBB}$ receptor targeting, we tried to determine whether receptor-mediated uptake could be observed into brain endothelial cells (bEND3 cells), known to express all the expected receptors tested [52]. Here, the P$\mathrm{PMO}$ conjugates were labeled with a Cy5 fluorescent dye [31] and their cell uptake measured by flow cytometry in a competition binding assay in the absence or presence of a 10fold excess of unlabelled peptides (data not shown). Although all P-PMOs tested were taken up well into bEND3 brain endothelial cells, no differences were observed between the cells incubated with Cy5-labeled P-PMO conjugates alone and cells coincubated with Cy5-labelled P-PMO conjugates and an excess of unlabelled peptides and, thus, no conclusions as to whether a receptor-mediated uptake mechanism occurs in these cells could be drawn.

\section{In vivo splice-switching activity of P-PMOs in neonatal SMA mice}

Based on the above cellular activity data in Dmd exonskipping in muscle cells and SMN2 exon-inclusion assays in SMA patient fibroblasts, we selected P-PMOs with the highest cell activity and low toxicity for assay in vivo. We chose a neonatal SMA mouse model that allows for screening of a larger number of P-PMOs than is the case for adult mice and at a lower dose, which, therefore, reduces the synthesis requirement. Thus, neonatal SMA mice (Smn $1^{\text {tm1Hung/wt; }}$ $\mathrm{SMN} 2^{\mathrm{tg} / \mathrm{tg}}$ and $\mathrm{Smn} 1^{\mathrm{wt} / \mathrm{wt}} ; \mathrm{SMN} 2^{\mathrm{tg} / \mathrm{tg}}$ ) [33] at PND4 were treated with P-PMO conjugates $(2.66 \mathrm{nmol}$, two doses at $10 \mathrm{mg} / \mathrm{kg}$ ). PND4 is the most developed stage in which a pup can be treated by facial vein administration. The effect of the P-PMOs on the increase of full-length SMN2 pre-mRNA was determined by measurement of the changes in the levels of full-length SMN2 pre-mRNA relative to total SMN2 transcripts 7 days after treatment by quantitative PCR (qPCR; Fig. 4A). Among the P-PMOs tested, Br-ApoE $(\mathrm{K} \rightarrow \mathrm{A})$ was the only conjugate which displayed SMN2 exon 7 inclusion activity in all three organs tested, that is, brain, kidney, and

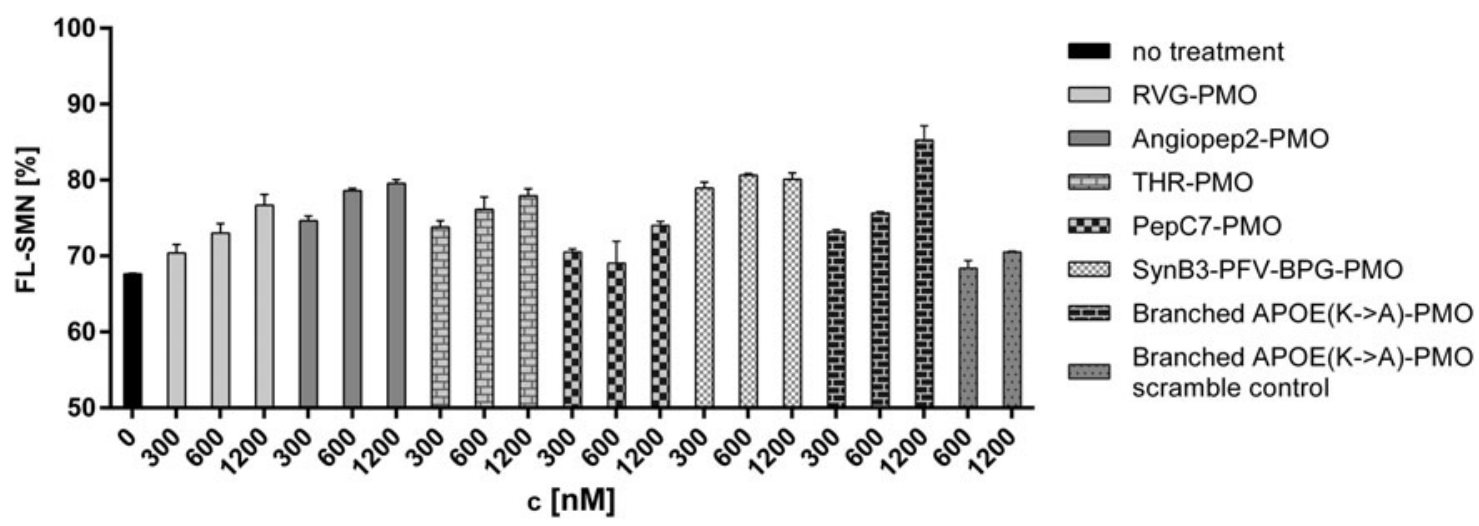

FIG. 3. Effect of P-PMO conjugate treatment on SMN2 exon 7 inclusion in cultured SMA patient-derived fibroblast cells. The average percentage increase in full-length SMN2 at three different concentrations of P-PMO conjugates was determined by densitometric analysis of RT-PCR gel images. SMA, spinal muscular atrophy; SMN2, survival motor neuron 2. 

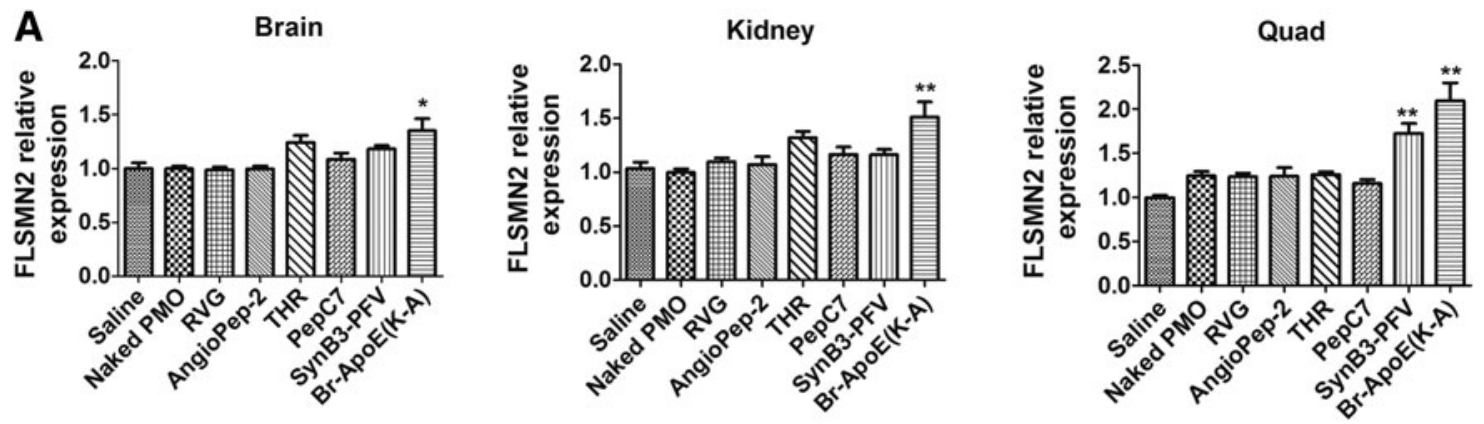

\begin{tabular}{|l|l|l|l|}
\hline \multicolumn{1}{|c|}{ P-PMO } & \multicolumn{1}{c|}{ Brain } & \multicolumn{1}{c|}{ Kidney } & \multicolumn{1}{c|}{ Quad } \\
\hline Saline $(\mathbf{n}=\mathbf{4})$ & $1 \pm 0.05$ & $1.04 \pm 0.06$ & $1 \pm 0.02$ \\
\hline Naked PMO $(\mathbf{n}=\mathbf{6})$ & $1 \pm 0.02$ & $1 \pm 0.04$ & $1.25 \pm 0.05$ \\
\hline RVG $(\mathbf{n}=\mathbf{5})$ & $1 \pm 0.02$ & $1.1 \pm 0.03$ & $1.23 \pm 0.04$ \\
\hline AngioPep-2 $(\mathbf{n}=\mathbf{5})$ & $1 \pm 0.03$ & $1.07 \pm 0.07$ & $1.24 \pm 0.1$ \\
\hline THR $(\mathbf{n}=\mathbf{5})$ & $1.24 \pm 0.07$ & $1.32 \pm 0.06$ & $1.26 \pm 0.03$ \\
\hline PepC7 $(\mathbf{n}=\mathbf{5})$ & $1.09 \pm 0.06$ & $1.16 \pm 0.07$ & $1.16 \pm 0.04$ \\
\hline SynB3-PFV $(\mathbf{n}=\mathbf{4})$ & $1.18 \pm 0.03$ & $1.16 \pm 0.05$ & $1.73 \pm 0.11 * *$ \\
\hline Br-ApoE $(\mathbf{K} \longrightarrow \mathbf{A})(\mathbf{n}=\mathbf{5})$ & $1.35 \pm 0.11 *$ & $1.5 \pm 0.14 * *$ & $2.1 \pm 0.21 * *$ \\
\hline
\end{tabular}

FIG. 4. (A) In vivo screening of P-PMO conjugates targeting SMN2 exon 7 inclusion in SMA mice at PND4. The increase of full-length $S M N 2$ transcript in the brain, kidney, and quadriceps following facial vein injection was determined using real-time reverse transcriptase quantitative polymerase chain reaction (RT-qPCR). The branched ApoE $(\mathrm{K} \rightarrow \mathrm{A})-\mathrm{PMO}$ was the only P-PMO, which showed a significant increase in the levels of full-length $S M N 2$ transcript in all three tissues compared with the control (saline and naked PMO)-treated groups. (B) Level of full-length SMN2 transcript in newborn SMA mice treated with P-PMO measured using RT-qPCR. The change in the level of full-length SMN2 transcripts expression was normalized to the total $S M N 2$ transcripts. Data are presented as mean \pm SEM. $* P<0.05, * * P<0.001$ cf. saline and naked PMO-treated groups. PND, postnatal day; SEM, standard error of the mean.

quadriceps, whereas the levels of SMN2 exon 7 inclusion activity for other P-PMO conjugates were not statistically significant compared with the saline and naked PMO-treated groups. The level of full-length $S M N 2$ pre-mRNA in the brain measured for $\mathrm{Br}-\mathrm{ApoE}(\mathrm{K} \rightarrow \mathrm{A})-\mathrm{PMO}(1.35 \pm 0.11, n=5)$ was higher than that for saline-treated $(1 \pm 0.05, n=4)$ and naked PMO-treated mice $(1 \pm 0.02, n=6)$. Br-ApoE $(\mathrm{K} \rightarrow \mathrm{A})$-PMO also displayed a significantly higher activity in a skeletal muscle (quadriceps) tissue $(2.1 \pm 0.21, n=5)$ as well as in kidney $(1.5 \pm 0.14, n=5)$ (Fig. 4B).

\section{Phenotypic correction of neonatal SMA mice treated with P-PMO}

Following identification of $\mathrm{Br}-\mathrm{ApoE}(\mathrm{K} \rightarrow \mathrm{A})-\mathrm{PMO}$ as the most active conjugate with significant SMN2 spliceswitching activity in the brain as well as in skeletal muscle, its effect on the survival, weight gain, righting reflex, and hindlimb strength of newborn SMA mice was assessed. SMA mice were treated with SMA-PMO, Br-ApoE $(\mathrm{K} \rightarrow \mathrm{A})-\mathrm{PMO}$, and $\mathrm{Br}-\mathrm{ApoE}(\mathrm{K} \rightarrow \mathrm{A})$-scrambled-PMO (two doses of $10 \mathrm{mg}$ / $\mathrm{kg}, 1.48 \mathrm{nmol})$ at PND0 and PND2. The Br-ApoE $(\mathrm{K} \rightarrow \mathrm{A})-$ scrambled-PMO-treated mice had a median survival of 14 days, which was not significantly different to that of saline-treated mice that had a median survival of 10.5 days
(Fig. 5A). The naked SMA-PMO-treated mice survived a median of 29 days. However, the $\mathrm{Br}-\mathrm{ApoE}(\mathrm{K} \rightarrow \mathrm{A})-\mathrm{PMO}$ treatment led to a significant increase in the median survival of the newborn SMA mice to 78 days $(P<0.0005$ Log-rank Mantel-Cox; Supplementary Table S1). The Br-ApoE ( $\mathrm{K} \rightarrow$ A)-PMO-treated mice also showed an increased weight gain compared with naked PMO-treated mice (Fig. 5B). The hindlimb strength (Fig. 5C) and righting ability (Fig. 5D) were also significantly improved from PND2 up to PND12 [34], during which time untreated SMA mice will become progressively weaker.

\section{In vivo splice-switching activity of P-PMO in adult SMA mice}

We have shown that multiple dosing of Br-ApoE-(K-A)PMO had a significant effect in alleviating the SMA phenotype in newborn SMA mice. Subsequently, we decided to study the effect of this P-PMO in restoring full-length $S M N 2$ transcript and SMN protein in adult SMA mice, which tests in particular the CNS uptake ability of this P-PMO. The BrApoE $(\mathrm{K} \rightarrow \mathrm{A})-\mathrm{PMO}$ was found to restore full-length $S M N 2$ both in the CNS as well as in the periphery. Treatment of adult SMA mice with 6 weekly doses of $10 \mathrm{mg} / \mathrm{kg} \mathrm{Br}-\mathrm{ApoE}$ $(\mathrm{K} \rightarrow \mathrm{A})$-PMO resulted in significant changes in the levels of 

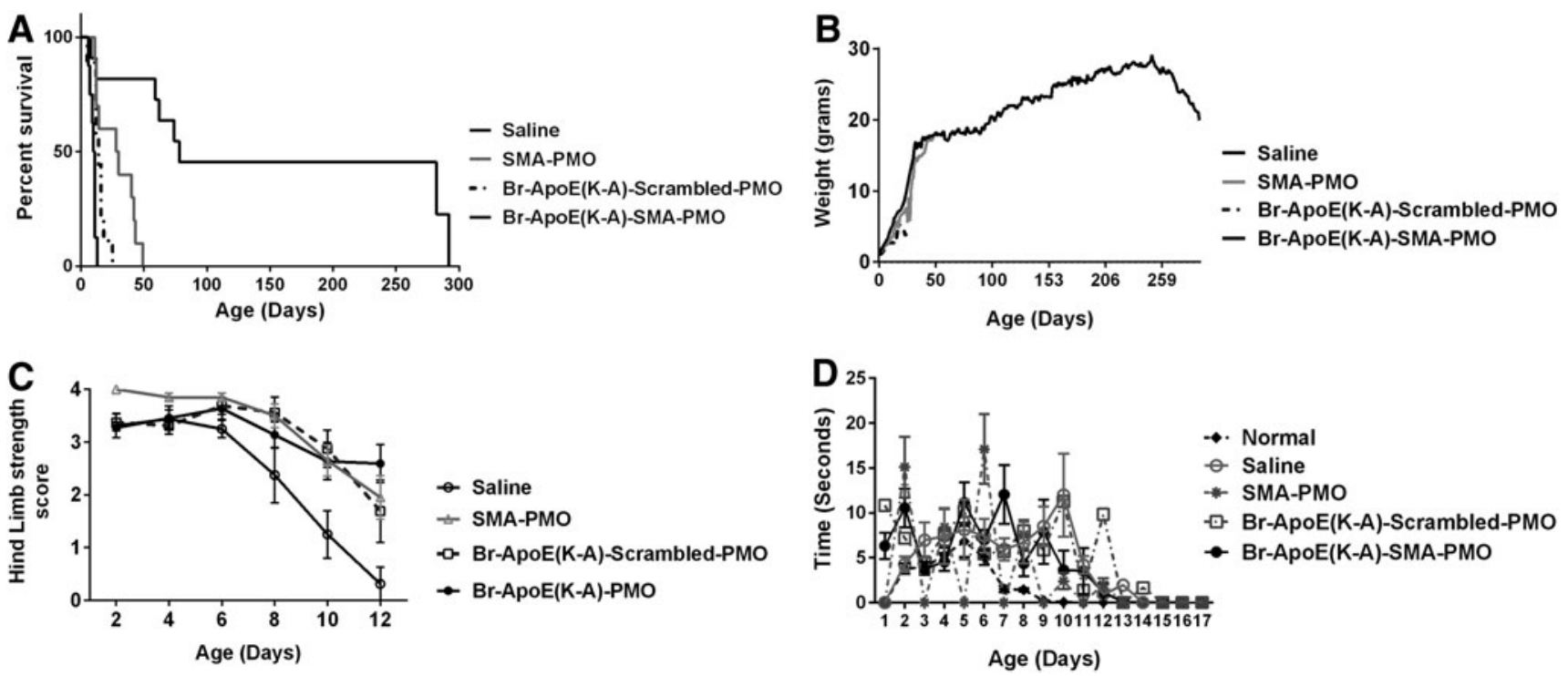

FIG. 5. Treatment of severe SMA (Smn $\left.1^{\text {tm1Hung/tm1Hung }} ; \mathrm{SMN} 2^{\text {tg/o }}\right)$ mice with two doses of $10 \mathrm{mg} / \mathrm{kg}$ at PND0 and PND2 with Br-ApoE $(\mathrm{K} \rightarrow \mathrm{A})$-PMO administered through facial vein injection resulted in a marked increase in (A) the median survival to 78 days, and (B) steady increased weight gain compared with the untreated, naked $\mathrm{PMO}-$ treated, and $\mathrm{Br}-\mathrm{ApoE}$ $(\mathrm{K} \rightarrow \mathrm{A})$-scrambled-PMO-treated groups. (C) Muscle strength, measured by the hindlimb suspension "tube test," was maintained for Br-ApoE $(\mathrm{K} \rightarrow \mathrm{A})$-PMO until PND12, whereas the saline, naked, and Br-ApoE $(\mathrm{K} \rightarrow \mathrm{A})$-scrambled-PMO showed a gradual decline in muscle strength. (D) The Br-ApoE $(\mathrm{K} \rightarrow \mathrm{A})-\mathrm{PMO}$-treated pups showed improvement in their righting ability.

full-length SMN2 transcript in kidney, in all three regions of the spinal cord and in the brain stem, although no changes could be detected in the cerebellum and cortex (Fig. 6). In addition to $\mathrm{qPCR}$, we tested the levels of SMN protein in saline- and Br-ApoE ( $\mathrm{K} \rightarrow \mathrm{A})$-PMO-treated tissues (Supplementary Fig. S2). A significant increase in the level of SMN protein was observed in kidney. Unfortunately, the western blots were not sensitive enough to detect significant changes in protein expression in the spinal cord, despite increases in the levels of full-length $S M N 2$ pre-mRNA detected by qPCR. Serum chemistry from adult mice collected after two doses of $10 \mathrm{mg} / \mathrm{kg} \quad$ Br-ApoE $(\mathrm{K} \rightarrow \mathrm{A})-\mathrm{PMO}, \quad B r-A p o E \quad(\mathrm{~K} \rightarrow \mathrm{A})-$ scrambled $\mathrm{PMO}$ or untreated was analyzed for alanine transaminase (ALT), aspartate transaminase (AST), creatinine, urea, and total protein. All levels were within the normal range for FVB/N mice (Supplementary Table S2).

\section{Discussion}

Gene-targeting oligonucleotide analogues, such as PMO, PNA, and 2'-OMe/PS, have shown great promise for the treatment of various neuromuscular and neurodegenerative genetic diseases [53]. In most cases, these antisense oligonucleotides are designed to modulate the aberrant splicing of pre-mRNA in favor of producing a therapeutically relevant RNA transcript. SSOs are being developed for the treatment
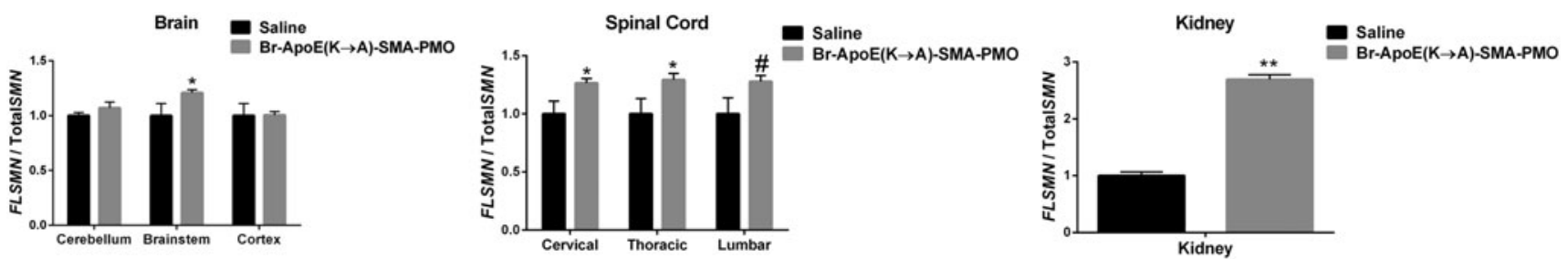

\begin{tabular}{|c|c|c|c|c|c|c|c|}
\hline \multirow{2}{*}{ P-PMO } & \multicolumn{3}{|c|}{ Brain } & \multicolumn{3}{|c|}{ Spinal cord } & \multirow{2}{*}{ Kidney } \\
\hline & Cerebellum & Brain stem & Cortex & Cervical & Thoracic & Lumbar & \\
\hline Saline & $1 \pm 0.015$ & $1 \pm 0.049$ & $1 \pm 0.045$ & $1 \pm 0.045$ & $1 \pm 0.058$ & $1 \pm 0.056$ & $1 \pm 0.03$ \\
\hline $\begin{array}{c}\text { Br-ApoE }(K \rightarrow A)- \\
\text { SMA-PMO }\end{array}$ & $1.069 \pm 0.027$ & $1.21 \pm 0.016^{*}$ & $1 \pm 0.018$ & $1.26 \pm 0.019^{\star}$ & $1.3 \pm 0.028^{*}$ & $1.28 \pm 0.03^{\#}$ & $2.7 \pm 0.041^{\star \star}$ \\
\hline
\end{tabular}

FIG. 6. Quantitative real-time PCR analysis of relative expression of full-length SMN2 in the brain, spinal cord, and kidney of adult SMA mice treated with $\mathrm{Br}-\mathrm{ApoE}(\mathrm{K} \rightarrow \mathrm{A})$-PMO with 6 weekly doses of $10 \mathrm{mg} / \mathrm{kg}$ and harvested $7 \mathrm{days}$ post final administration. Data are presented as mean \pm SEM. ${ }^{\#} P<0.01,{ }^{*} P<0.001$, $* * P<0.0001$ cf. saline-treated groups. PCR, polymerase chain reaction. 
of various CNS diseases such as frontotemporal dementia (FTD) [54], Menkes disease [55], Huntington's disease [56], amyotrophic lateral sclerosis [57], and SMA [58-62]. However, poor cellular uptake and BBB permeability have been roadblocks to systemically delivered oligonucleotide clinical applications. To date, most in vivo studies of SSOs have therefore been carried out using intra-cerebral ventricular (ICV) or intrathecal injections [53], including the $2^{\prime}-O$ methoxyethyl-modified SSO (Nusinersen, ISIS-SMN $\mathrm{RX}_{\mathrm{RX}}$ ) that is currently in clinical trials by Ionis/Biogen Pharmaceuticals that requires multiple intrathecal injections in SMA patients who are mostly infants (ClinicalTrial.gov Identifier: NCT01839656).

PMO is used in several clinical and preclinical studies due to its high stability and low toxicity [63,64]. The PMO sequence PMO20, also known as HSMN2Ex7D(-10,-29), has been previously studied by Porensky et al. [61]. Single ICV injections $(27,54$, and $81 \mu \mathrm{g})$ of this PMO in newborn SMN $\Delta 7$ mice at P0 increased the levels of both full-length SMN2 RNA transcript in the brain and spinal cord as well as SMN protein and yielded an increased survival of $>100$ days. In a similar study, Zhou et al. [65] used the same PMO sequence $[\mathrm{PMO} 20(-10,-29)]$ as well as PMO18 $(-10,-27)$ and PMO25 $(-10,-34)$. The survival data obtained following ICV injection of PMO25 $(40 \mu \mathrm{g} / \mathrm{g})$ was comparable to that of PMO20 obtained by Porensky et al. In this study, the PMO was conjugated with an octa-guanidine dendrimer (vivomorpholino), which were shown previously to be effective for splice switching in DMD mice [66]. However, an ICV injection $(10 \mathrm{mg} / \mathrm{kg})$ of vivo-PMO25 designed for SMN2 exon 7 inclusion led to the death of all mice and a dose of $4 \mathrm{mg} / \mathrm{kg}$ resulted in hydrocephalus [66]. Systemic administration of vivo-PMO25 also failed to restore full-length SMN2 in the brain, demonstrating the limitations of an octaguanidine dendrimer as a PMO delivery vector into the CNS.

By contrast, arginine-rich CPPs have been much used for the systemic delivery of PMO into cardiac and skeletal muscles to enhance dystrophin expression in DMD mouse model $[13,18,32,51,67,68]$. Very recently, we reported the use of the CPP Pip6a for delivery of PMO into the brain or CNS from the circulation, a prerequisite for its systemic application to diseases such as SMA [20]. This current study was aimed at cellular and in vivo screening to identify other novel peptides active both in splice switching in cells (muscle and SMA patient fibroblasts) and in systemic delivery of a PMO SSO into SMA mouse models to restore $S M N 2$ expression both in skeletal muscle as well as in the CNS. The SMA mouse pup model is particularly relevant to the disease since SMN protein is required for motor neuron development during the early postnatal stages of development [69-71]. Exon inclusion of SMN2 pre-mRNA and increase of the SMN protein level can lead to the extension of survival, which can serve as a good phenotypic readout.

In the initial cell prescreening for splice-switching efficiencies of the P-PMO conjugates in differentiated mouse $\mathrm{H} 2 \mathrm{~K} m d x$ cells (Fig. 1), branched and tandem dimers of ApoE-PMO were identified as particularly active compared with naked PMO. However, in subsequent cell viability evaluations (Fig. 2), a high level of cytotoxicity was observed for these P-PMOs, perhaps due to the very high number of cationic amino acids [72]. By contrast, cytotoxicity was significantly reduced when we replaced Lys residues by Ala in $[\mathrm{Br}-\mathrm{ApoE}(\mathrm{K} \rightarrow \mathrm{A})-\mathrm{PMO}$, to give a branched peptide having less positive charges, but splice-switching efficiency was still maintained. Lys residues were substituted rather than Arg due to the suggestion of more efficient cell-penetrating ability by Arg-containing cell-penetrating peptides than for Lys [73]. In line with the $D M D$ exon-skipping results in $\mathrm{H} 2 \mathrm{~K} m d x$ cells, Br-ApoE $(\mathrm{K} \rightarrow \mathrm{A})-\mathrm{PMO}$ showed the highest spliceswitching activity in further screening in SMA type I fibroblasts for SMN2 exon 7 inclusion (Fig. 3), which is an established SMA cell assay, but with a lower dynamic range than in the prescreen using the DMD exon-skipping assay.

To address the in vivo systemic delivery of PMO by the novel peptides in a high-throughput manner, we carried out the screening of P-PMOs in newborn SMA mice at PND4, the latest age at which conjugates could be reliably administered through the facial vein. Of the conjugates tested, only $\mathrm{Br}$ ApoE $(\mathrm{K} \rightarrow \mathrm{A})$-PMO showed SMN2 exon 7 inclusion in all these three organs assessed, brain, kidney, and quadriceps (Fig. 4) that were statistically significant compared with control saline- and naked PMO-treated mice.

Besides Br-ApoE $(\mathrm{K} \rightarrow \mathrm{A})$, SynB3PFV (which includes the SynB3 peptide) also induced a significant increase in the level of full-length SMN2 transcript in quadriceps, but not in other organs, including brain. SynB3 has been shown previously to enhance the in vivo brain uptake of bio-cargoes such as dalargin [46] and PEGylated nanoparticles [74]. Note that this peptide is moderately cationic (five Arg residues) and therefore it may be acting in quadriceps like a CPP [18]. SynB3 and SynB3PFV peptides also showed very high splice-switching ability in $\mathrm{H} 2 \mathrm{~K} m d x$ muscle cells (Fig. 1B). However, the ability of $\mathrm{Br}-\mathrm{ApoE}(\mathrm{K} \rightarrow \mathrm{A})$ to be active both in brain and in skeletal muscle tissue gives this peptide a particular advantage for further SMA therapeutic development. The branched arrangement of this peptide also resulted in slightly more serum stability than for the tandem dimer of ApoE and may provide a better clustering of guanidinium groups of Arg to bind the negatively charged glycans on the cell surface for endocytotic uptake of the peptide [75,76].

Unfortunately no data could be obtained on the likely mechanism of transcytosis, since competition experiments in brain endothelial cells that are known to express the ApoE receptor proved inconclusive. The branched peptide is also Arg rich. Thus, whether receptor-mediated or absorptive transcytosis occurs across the BBB for Br-ApoE $(\mathrm{K} \rightarrow \mathrm{A})$ $\mathrm{PMO}$ or some combination of the two mechanisms remains unclear. There is also the possibility of uptake through the blood-cerebrospinal fluid barrier into the ventricular system. However, a full understanding of the exact mechanism(s) of transcytosis by this peptide in vivo is challenging to establish and is well beyond the scope of the current article.

Evaluation of Br-ApoE $(\mathrm{K} \rightarrow \mathrm{A})$-PMO for rescue of the SMA phenotype [65] resulted in a significant extension of the median survival of the SMA mouse pups to 78 days with two mice surviving to 282 and 290 days, respectively. The BrApoE $(\mathrm{K} \rightarrow \mathrm{A})$-PMO-treated mice also showed an increased weight gain and higher muscle strength compared with the naked PMO-treated mice as well as improvements in righting ability compared with saline and $\mathrm{Br}-\mathrm{ApoE}(\mathrm{K} \rightarrow \mathrm{A})$ Scrambled-PMO-treated mice. The pups were tested from PND2 to PND12 since the untreated, naked-PMO, and BrApoE $(\mathrm{K} \rightarrow \mathrm{A})$-Scrambled-PMO-treated pups do not survive beyond PND12. In all tests, Br-ApoE ( $\rightarrow A$ )-PMO-treated pups showed significant and sustained survival, weight gain, muscle strength, and righting reflex. 
Particularly interesting were the observed effects of $\mathrm{Br}$ ApoE $(\mathrm{K} \rightarrow \mathrm{A})$-PMO to increase the levels of full-length $S M N 2$ and SMN protein in adult SMA mice, where the BBB is much less permeable. Six weekly intravenous doses of $\mathrm{Br}$ $\operatorname{ApoE}(\mathrm{K} \rightarrow \mathrm{A})-\mathrm{PMO}(10 \mathrm{mg} / \mathrm{kg})$ resulted in an increase in the levels of full-length SMN2 pre-mRNA both in the CNS as well as in skeletal muscle and in kidney. Unfortunately, the changes in SMN protein levels could not be determined because of lack of sensitivity in the western blot assay (Supplementary Fig. S2). Nevertheless, the exon inclusion results did show that $\mathrm{Br}-\mathrm{ApoE}(\mathrm{K} \rightarrow \mathrm{A})$ is capable of delivering its conjugated PMO into a skeletal muscle and into the CNS and this is of great significance for the treatment of SMA. While it is currently unclear where in the CNS the ApoE peptide is able to deliver PMO, future studies will be conducted to elucidate this information for further applications of PMO delivery.

SMN protein is ubiquitously expressed and highly conserved across species, its expression peaking during development [77], and lower motor neurons are thought to be the primary target in SMA. We do not have in vivo evidence at this stage of neuronal cell uptake in brain/spinal cord for our P-PMO. Nor has any evidence of such uptake been presented for naked PMO injected intrathecally into SMA mouse brain, which showed substantial mouse survival enhancement [61]. Such experiments will require a separate study needing significant quantities of labeled P-PMO. Thus, whether the exon inclusion seen in adult SMA mice in brain and spinal cord by systemic Br-ApoE $(\mathrm{K} \rightarrow \mathrm{A})$-PMO injection occurs in neurons, glial cells, or endothelial cells, or some combination, cannot currently be determined, but the extension of survival seen in the severe SMA mice may suggest that at least some exon inclusion could be occurring in neurons.

An increasing number of clinical and experimental studies are emerging that indicate the involvement of peripheral organs in the pathogenesis of SMA [78]. Therefore, a bodywide increase in full-length SMN2 pre-mRNA through exon inclusion demonstrated in our results and, therefore, in SMN protein, is more desirable than just in the CNS. The current clinical trials with Nusinersen are carried out using multiple intrathecal injections. This can have several drawbacks, including complications related to lumbar puncture, poor CNS distribution of SSOs and lack of any therapeutic benefits for the peripheral pathological component of the disease. A recent study in SMA mice has also shown that subcutaneous administration of several low doses of PMO had a greater effect in increasing the average survival of SMA mice than a single high-dose ICV bolus injection [79]. In this study, however, we have shown the greater benefits of using a PPMO conjugate as compared with a naked PMO oligonucleotide by a significant alleviation of the SMA phenotypes.

Our results are comparable to the activity in spinal cord in adult mice for our previous Pip6a-PMO [20]. However, this peptide is longer and contains a higher number of positively charged Arg residues. Initial indications are that Pip6a may not have a sufficiently favorable therapeutic index for clinical development (Godfrey et al., unpublished results). It is clear from the current study that novel peptides are discoverable beyond the Pip series of which Br-ApoE $(\mathrm{K} \rightarrow \mathrm{A})-\mathrm{PMO}$ is the first new example for SMA application. Ongoing work aims to carry out detailed in vivo studies in parallel of both activity and toxicology to identify novel peptides with acceptable therapeutic index that may be suitable leads for drug development. However, we believe the current work paves the way for the development of a peptide-based systemic delivery platform into both skeletal tissue and CNS for SSO treatment of SMA that perhaps might be extended to other neuromuscular and neurodegenerative diseases.

\section{Acknowledgments}

The authors thank Andrey Arzumanov, Amer Saleh, Peter Järver (MRC-LMB), and Melissa Bowerman (Oxford) for their advice and the academic support of the MDEX Consortium (www.mdex.org.uk) is also acknowledged. Work in the laboratory of M.J.G. was supported by the Medical Research Council (MRC program no. U105178803) and in the laboratory of M.J.A.W. by (SMA Europe and MRC program no. G0900887). M.J.G. and M.J.A.W. acknowledge a development grant (MR/L013142/1) from the MRC Development Pathway Funding Scheme. F.S. is a recipient of a CJ Martin Fellowship from the Australian National Health and Medical Research Council and also acknowledges support by the Bethlehem Griffith Research Foundation (BGRF1501).

\section{Author Disclosure Statement}

No competing financial interests exist.

\section{References}

1. Crawford TO and CA Pardo. (1996). The neurobiology of childhood spinal muscular atrophy. Neurobiol Dis 3:97-110.

2. Lefebvre S, L Burglen, S Reboullet, O Clermont, P Burlet, L Viollet, B Benichou, C Cruaud, $\mathrm{P}$ Millasseau, et al. (1995). Identification and characterization of a spinal muscular atrophy-determining gene. Cell 80:155-165.

3. Monani UR, CL Lorson, DW Parsons, TW Prior, EJ Androphy, AH Burghes and JD McPherson. (1999). A single nucleotide difference that alters splicing patterns distinguishes the SMA gene SMN1 from the copy gene SMN2. Hum Mol Genet 8:1177-1183.

4. Lorson CL, E Hahnen, EJ Androphy and B Wirth. (1999). A single nucleotide in the SMN gene regulates splicing and is responsible for spinal muscular atrophy. Proc Natl Acad Sci U S A 96:6307-6311.

5. Le TT, LT Pham, ME Butchbach, HL Zhang, UR Monani, DD Coovert, TO Gavrilina, L Xing, GJ Bassell and AH Burghes. (2005). SMNDelta7, the major product of the centromeric survival motor neuron (SMN2) gene, extends survival in mice with spinal muscular atrophy and associates with full-length SMN. Hum Mol Genet 14:845-857.

6. Lefebvre S, P Burlet, Q Liu, S Bertrandy, O Clermont, A Munnich, G Dreyfuss and J Melki. (1997). Correlation between severity and SMN protein level in spinal muscular atrophy. Nat Genet 16:265-269.

7. Feldkotter M, V Schwarzer, R Wirth, TF Wienker and B Wirth. (2002). Quantitative analyses of SMN1 and SMN2 based on real-time lightCycler PCR: fast and highly reliable carrier testing and prediction of severity of spinal muscular atrophy. Am J Hum Genet 70:358-368.

8. Koo T and MJ Wood. (2013). Clinical trials using antisense oligonucleotides in duchenne muscular dystrophy. Hum Gene Ther 24:479-488.

9. Singh NN, BM Lee, CJ DiDonato and RN Singh. (2015). Mechanistic principles of antisense targets for the treatment of spinal muscular atrophy. Future Med Chem 7:1793-1808. 
10. BIOGEN and Ionis Pharmaceuticals. Biogen completes rolling submission of new drug application to FDA for Nusinersen as a treatment for spinal muscular atrophy. http://media.biogen.com/press-release/neurodegenerativediseases/biogen-completes-rolling-submission-new-drugapplication-fd (accessed September 26, 2016).

11. Hache M, KJ Swoboda, N Sethna, A Farrow-Gillespie, A Khandji, S Xia and KM Bishop. (2016). Intrathecal injections in children with spinal muscular atrophy: Nusinersen clinical trial experience. J Child Neurol 31:899-906.

12. Manjila SB, JN Baby, EN Bijin, I Constantine, K Pramod and J Valsalakumari. (2013). Novel gene delivery systems. Int J Pharm Investig 3:1-7.

13. Betts CA and MJ Wood. (2013). Cell penetrating peptide delivery of splice directing oligonucleotides as a treatment for Duchenne muscular dystrophy. Curr Pharm Des 19: 2948-2962.

14. Boisguerin P, S Deshayes, MJ Gait, L O'Donovan, C Godfrey, CA Betts, MJ Wood and B Lebleu. (2015). Delivery of therapeutic oligonucleotides with cell penetrating peptides. Adv Drug Deliv Rev 87:52-67.

15. Järver P, L O'Donovan and MJ Gait. (2014). A chemical view of oligonucleotides for exon skipping and related drug applications. Nucleic Acid Ther 24:37-47.

16. Yin H, C Betts, AF Saleh, GD Ivanova, H Lee, Y Seow, D Kim, MJ Gait and MJA Wood. (2010). Optimization of peptide nucleic acid antisense oligonucleotides for local and systemic dystrophin splice correction in the $\mathrm{mdx}$ mouse. Mol Ther 18:819-827.

17. Yin HF, HM Moulton, C Betts, T Merritt, Y Seow, S Ashraf, QS Wang, J Boutilier and MJA Wood. (2010). Functional rescue of dystrophin-deficient mdx mice by a chimeric peptide-PMO. Mol Ther 18:1822-1829.

18. Betts C, AF Saleh, AA Arzumanov, SM Hammond, C Godfrey, T Coursindel, MJ Gait and MJ Wood. (2012). Pip6-PMO, A new generation of peptide-oligonucleotide conjugates with improved cardiac exon skipping activity for DMD treatment. Mol Ther Nucleic Acids 1:e38.

19. Yin H, HM Moulton, Y Seow, C Boyd, J Boutilier, P Iverson and MJA Wood. (2008). Cell-penetrating peptideconjugated antisense oligonucleotides restore systemic muscle and cardiac dystrophin expression and function. Hum Mol Genet 17:3909-3918.

20. Hammond SM, G Hazell, F Shabanpoor, AF Saleh, M Bowerman, JN Sleigh, KE Meijboom, H Zhou, F Muntoni, et al. (2016). Systemic peptide-mediated oligonucleotide therapy improves long-term survival in spinal muscular atrophy. Proc Natl Acad Sci U S A 113:10962-10967.

21. Farkhani SM, A Valizadeh, H Karami, S Mohammadi, N Sohrabi and F Badrzadeh. (2014). Cell penetrating peptides: efficient vectors for delivery of nanoparticles, nanocarriers, therapeutic and diagnostic molecules. Peptides 57:78-94.

22. Kang T, X Gao and J Chen. (2014). Harnessing the capacity of cell-penetrating peptides for drug delivery to the central nervous system. Curr Pharm Biotechnol 15:220-230.

23. Pardridge WM. (2012). Drug transport across the bloodbrain barrier. J Cereb Blood Flow Metab 32:1959-1972.

24. Price TO, SA Farr, X Yi, S Vinogradov, E Batrakova, WA Banks and AV Kabanov. (2010). Transport across the blood-brain barrier of pluronic leptin. J Pharmacol Exp Ther 333:253-263.

25. Yao H, K Wang, Y Wang, S Wang, J Li, J Lou, L Ye, X Yan, W Lu and R Huang. (2015). Enhanced blood-brain barrier penetration and glioma therapy mediated by a new peptide modified gene delivery system. Biomaterials 37: 345-352.

26. Wei X, C Zhan, Q Shen, W Fu, C Xie, J Gao, C Peng, P Zheng and $\mathrm{W} \mathrm{Lu}$. (2015). A D-peptide ligand of nicotine acetylcholine receptors for brain-targeted drug delivery. Angew Chem Int Ed Engl 54:3023-3027.

27. Bockenhoff A, S Cramer, P Wolte, S Knieling, C Wohlenberg, V Gieselmann, HJ Galla and U Matzner. (2014). Comparison of five peptide vectors for improved brain delivery of the lysosomal enzyme arylsulfatase A. J Neurosci 34:3122-3129.

28. Hutcheson DA, MI Hanson, KB Moore, TT Le, NL Brown and ML Vetter. (2005). bHLH-dependent and -independent modes of Ath5 gene regulation during retinal development. Development 132:829-839.

29. Ellman GL. (1959). Tissue sulfhydryl groups. Arch Biochem Biophys 82:70-77.

30. Mitrpant C, P Porensky, H Zhou, L Price, F Muntoni, S Fletcher, SD Wilton and AH Burghes. (2013). Improved antisense oligonucleotide design to suppress aberrant SMN2 gene transcript processing: towards a treatment for spinal muscular atrophy. PloS One 8:e62114.

31. Shabanpoor F and MJ Gait. (2013). Development of a general methodology for labelling peptide-morpholino oligonucleotide conjugates using alkyne-azide click chemistry. Chem Commun (Camb) 49:10260-10262.

32. Shabanpoor F, G McClorey, AF Saleh, P Jarver, MJ Wood and MJ Gait. (2015). Bi-specific splice-switching PMO oligonucleotides conjugated via a single peptide active in a mouse model of Duchenne muscular dystrophy. Nucleic Acids Res 43:29-39.

33. Gogliotti RG, SM Hammond, C Lutz and CJ Didonato. (2010). Molecular and phenotypic reassessment of an infrequently used mouse model for spinal muscular atrophy. Biochem Biophys Res Commun 391:517-522.

34. El-Khodor BF, N Edgar, A Chen, ML Winberg, C Joyce, D Brunner, M Suarez-Farinas and MP Heyes. (2008). Identification of a battery of tests for drug candidate evaluation in the SMNDelta7 neonate model of spinal muscular atrophy. Exp Neurol 212:29-43.

35. Kumar P, H Wu, JL McBride, KE Jung, MH Kim, BL Davidson, SK Lee, P Shankar and N Manjunath. (2007). Transvascular delivery of small interfering RNA to the central nervous system. Nature 448:39-43.

36. Lentz TL. (1990). Rabies virus binding to an acetylcholine receptor alpha-subunit peptide. J Mol Recognit 3:82-88.

37. Zadran S, G Akopian, H Zadran, J Walsh and M Baudry. (2013). RVG-mediated calpain2 gene silencing in the brain impairs learning and memory. Neuromolecular Med 15:7481.

38. Demeule M, A Regina, C Che, J Poirier, T Nguyen, R Gabathuler, JP Castaigne and R Beliveau. (2008). Identification and design of peptides as a new drug delivery system for the brain. J Pharmacol Exp Ther 324:10641072.

39. Re F, I Cambianica, S Sesana, E Salvati, A Cagnotto, M Salmona, PO Couraud, SM Moghimi, M Masserini and G Sancini. (2010). Functionalization with ApoE-derived peptides enhances the interaction with brain capillary endothelial cells of nanoliposomes binding amyloid-beta peptide. J Biotechnol 156:341-346.

40. Re F, I Cambianica, C Zona, S Sesana, M Gregori, R Rigolio, B La Ferla, F Nicotra, G Forloni, et al. (2011). 
Functionalization of liposomes with ApoE-derived peptides at different density affects cellular uptake and drug transport across a blood-brain barrier model. Nanomedicine 7:551-559.

41. Lee JH, JA Engler, JF Collawn and BA Moore. (2001). Receptor mediated uptake of peptides that bind the human transferrin receptor. Eur J Biochem 268:2004-2012.

42. Liu JK, Q Teng, M Garrity-Moses, T Federici, D Tanase, MJ Imperiale and NM Boulis. (2005). A novel peptide defined through phage display for therapeutic protein and vector neuronal targeting. Neurobiol Dis 19:407-418.

43. Li J, Q Zhang, Z Pang, Y Wang, Q Liu, L Guo and X Jiang. (2012). Identification of peptide sequences that target to the brain using in vivo phage display. Amino Acids 42:2373-2381.

44. van Rooy I, S Cakir-Tascioglu, PO Couraud, IA Romero, B Weksler, G Storm, WE Hennink, RM Schiffelers and E Mastrobattista. (2010). Identification of peptide ligands for targeting to the blood-brain barrier. Pharm Res 27:673-682.

45. Guarnieri D, A Falanga, O Muscetti, R Tarallo, S Fusco, M Galdiero, S Galdiero and PA Netti. (2013). Shuttlemediated nanoparticle delivery to the blood-brain barrier. Small 9:853-862.

46. Rousselle C, P Clair, M Smirnova, Y Kolesnikov, GW Pasternak, S Gac-Breton, AR Rees, JM Scherrmann and J Temsamani. (2003). Improved brain uptake and pharmacological activity of dalargin using a peptide-vectormediated strategy. J Pharmacol Exp Ther 306:371-376.

47. Rhee $M$ and P Davis. (2006). Mechanism of uptake of C105Y, a novel cell-penetrating peptide. J Biol Chem 281: 1233-1240.

48. Jearawiriyapaisarn N, HM Moulton, B Buckley, J Roberts, P Sazani, S Fucharoen, PL Iversen and R Kole. (2008). Sustained dystrophin expression induced by peptideconjugated morpholino oligomers in the muscles of $\mathrm{mdx}$ mice. Mol Ther 16:1624-1629.

49. Yin H, HM Moulton, C Betts, T Merritt, Y Seow, S Ashraf, Q Wang, J Boutilier and MJ Wood. (2010). Functional rescue of dystrophin-deficient mdx mice by a chimeric peptide-PMO. Mol Ther 18:1822-1829.

50. Yin H, HM Moulton, C Betts, Y Seow, J Boutilier, PL Iverson and MJ Wood. (2009). A fusion peptide directs enhanced systemic dystrophin exon skipping and functional restoration in dystrophin-deficient mdx mice. Hum Mol Genet 18:4405-4414.

51. Yin H, AF Saleh, C Betts, P Camelliti, Y Seow, S Ashraf, A Arzumanov, S Hammond, T Merritt, MJ Gait and MJA Wood. (2011). Pip5 transduction peptides direct high efficiency oligonucleotide-mediated dystrophin exon skipping in heart and phenotypic correction in mdx mice. Mol Ther 19:1295-1303.

52. Wagner S, A Zensi, SL Wien, SE Tschickardt, W Maier, T Vogel, F Worek, CU Pietrzik, J Kreuter and H von Briesen. (2012). Uptake mechanism of ApoE-modified nanoparticles on brain capillary endothelial cells as a blood-brain barrier model. PloS One 7:e32568.

53. Evers MM, LJ Toonen and WM van Roon-Mom. (2015). Antisense oligonucleotides in therapy for neurodegenerative disorders. Adv Drug Deliv Rev 87:90-103.

54. Peacey E, L Rodriguez, Y Liu and MS Wolfe. (2012). Targeting a pre-mRNA structure with bipartite antisense molecules modulates tau alternative splicing. Nucleic Acids Res 40:9836-9849.

55. Madsen EC, PA Morcos, BA Mendelsohn and JD Gitlin. (2008). In vivo correction of a Menkes disease model using antisense oligonucleotides. Proc Natl Acad Sci U S A 105:3909-3914.

56. Evers MM, HD Tran, I Zalachoras, OC Meijer, JT den Dunnen, GJ van Ommen, A Aartsma-Rus and WM van Roon-Mom. (2014). Preventing formation of toxic N-terminal huntingtin fragments through antisense oligonucleotidemediated protein modification. Nucleic Acid Ther 24:4-12.

57. Donnelly CJ, PW Zhang, JT Pham, AR Haeusler, NA Mistry, S Vidensky, EL Daley, EM Poth, B Hoover, et al. (2013). RNA toxicity from the ALS/FTD C9ORF72 expansion is mitigated by antisense intervention. Neuron 80:415-428.

58. Nizzardo M, C Simone, S Salani, MD Ruepp, F Rizzo, M Ruggieri, C Zanetta, S Brajkovic, HM Moulton, et al. (2014). Effect of combined systemic and local morpholino treatment on the spinal muscular atrophy Delta7 mouse model phenotype. Clin Ther 36:340-356.e345.

59. Osman EY, MR Miller, KL Robbins, AM Lombardi, AK Atkinson, AJ Brehm and CL Lorson. (2014). Morpholino antisense oligonucleotides targeting intronic repressor Element1 improve phenotype in SMA mouse models. Mol Ther 23:4832-4845.

60. Osman EY, PF Yen and CL Lorson. (2012). Bifunctional RNAs targeting the intronic splicing silencer N1 increase SMN levels and reduce disease severity in an animal model of spinal muscular atrophy. Mol Ther 20:119-126.

61. Porensky PN, C Mitrpant, VL McGovern, AK Bevan, KD Foust, BK Kaspar, SD Wilton and AH Burghes. (2012). A single administration of morpholino antisense oligomer rescues spinal muscular atrophy in mouse. Hum Mol Genet 21:1625-1638.

62. Rigo F, SJ Chun, DA Norris, G Hung, S Lee, J Matson, RA Fey, H Gaus, Y Hua, et al. (2014). Pharmacology of a central nervous system delivered 2'-O-methoxyethylmodified survival of motor neuron splicing oligonucleotide in mice and non-human primates. J Pharmacol Exp Ther 350:46-55.

63. Cirak S, V Arechavala-Gomeza, M Guglieri, L Feng, S Torelli, K Anthony, S Abbs, ME Garralda, J Bourke, et al. (2011). Exon skipping and dystrophin restoration in patients with Duchenne muscular dystrophy after systemic phosphorodiamidate morpholino oligomer treatment: an open-label, phase 2, dose-escalation study. Lancet 378: 595-605.

64. Goemans NM, M Tulinius, JT van den Akker, BE Burm, PF Ekhart, N Heuvelmans, T Holling, AA Janson, GJ Platenburg, et al. (2011). Systemic administration of PRO051 in Duchenne's muscular dystrophy. N Engl J Med 364:1513-1522.

65. Zhou H, N Janghra, C Mitrpant, RL Dickinson, K Anthony, L Price, IC Eperon, SD Wilton, J Morgan and F Muntoni. (2013). A novel morpholino oligomer targeting ISS-N1 improves rescue of severe spinal muscular atrophy transgenic mice. Hum Gene Ther 24:331-342.

66. Wu B, Y Li, PA Morcos, TJ Doran, P Lu and QL Lu. (2009). Octa-guanidine morpholino restores dystrophin expression in cardiac and skeletal muscles and ameliorates pathology in dystrophic mdx mice. Mol Ther 17:864-871.

67. Malerba A, JK Kang, G McClorey, AF Saleh, L Popplewell, MJ Gait, MJA Wood and G Dickson. (2012). Dual myostatin and dystrophin exon skipping by morpholino nucleic acid oligomers conjugated to a cell-penetrating peptide is a promising therapeutic strategy for the treatment of duchenne muscular dystrophy. Mol Ther Nucleic Acids 1:e62. 
68. Moulton HM, S Fletcher, BW Neuman, G McClorey, DA Stein, S Abes, SD Wilton, MJ Buchmeier, B Lebleu and PL Iversen. (2007). Cell-penetrating peptide-morpholino conjugates alter pre-mRNA splicing of DMD (Duchenne muscular dystrophy) and inhibit murine coronavirus replication in vivo. Biochem Soc Trans 35:826-828.

69. Foust KD, X Wang, VL McGovern, L Braun, AK Bevan, AM Haidet, TT Le, PR Morales, MM Rich, AH Burghes and BK Kaspar. (2010). Rescue of the spinal muscular atrophy phenotype in a mouse model by early postnatal delivery of SMN. Nat Biotechnol 28:271-274.

70. Sleigh JN, TH Gillingwater and K Talbot. (2011). The contribution of mouse models to understanding the pathogenesis of spinal muscular atrophy. Dis Model Mech 4: 457-467.

71. Hammond SM, RG Gogliotti, V Rao, A Beauvais, R Kothary and CJ DiDonato. (2010). Mouse survival motor neuron alleles that mimic SMN2 splicing and are inducible rescue embryonic lethality early in development but not late. PloS One 5:e15887.

72. Jrver P, T Coursindel, SE Andaloussi, C Godfrey, MJ Wood and MJ Gait. (2012). Peptide-mediated cell and in vivo delivery of antisense oligonucleotides and siRNA. Mol Ther Nucleic Acids 1:e27.

73. Amand HL, K Fant, B Norden and EK Esbjorner. (2008). Stimulated endocytosis in penetratin uptake: effect of arginine and lysine. Biochem Biophys Res Commun 371: 621-625.

74. Tian XH, F Wei, TX Wang, P Wang, XN Lin, J Wang, D Wang and L Ren. (2012). In vitro and in vivo studies on gelatin-siloxane nanoparticles conjugated with SynB peptide to increase drug delivery to the brain. Int J Nanomedicine 7:1031-1041.
75. Saleh AF, A Arzumanov, R Abes, D Owen, B Lebleu and MJ Gait. (2010). Synthesis and splice-redirecting activity of branched, arginine-rich peptide dendrimer conjugates of peptide nucleic acid oligonucleotides. Bioconjug Chem 21:1902-1911.

76. Ziegler A and J Seelig. (2008). Binding and clustering of glycosaminoglycans: a common property of mono- and multivalent cell-penetrating compounds. Biophys J 94: 2142-2149.

77. Tiziano FD, J Melki and LR Simard. (2013). Solving the puzzle of spinal muscular atrophy: what are the missing pieces? Am J Med Genet A 161A:2836-2845.

78. Shababi M, CL Lorson and SS Rudnik-Schoneborn. (2014). Spinal muscular atrophy: a motor neuron disorder or a multi-organ disease? J Anat 224:15-28.

79. Zhou H, J Meng, E Marrosu, N Janghra, J Morgan and F Muntoni. (2015). Repeated low doses of morpholino antisense oligomer: an intermediate mouse model of spinal muscular atrophy to explore the window of therapeutic response. Hum Mol Genet 24:6265-6277.

Address correspondence to: Michael J. Gait, PhD

Medical Research Council Laboratory of Molecular Biology Francis Crick Avenue Cambridge CB2 OQH United Kingdom

E-mail: mgait@mrc-lmb.cam.ac.uk

Received for publication October 13, 2016; accepted after revision December 19, 2016. 